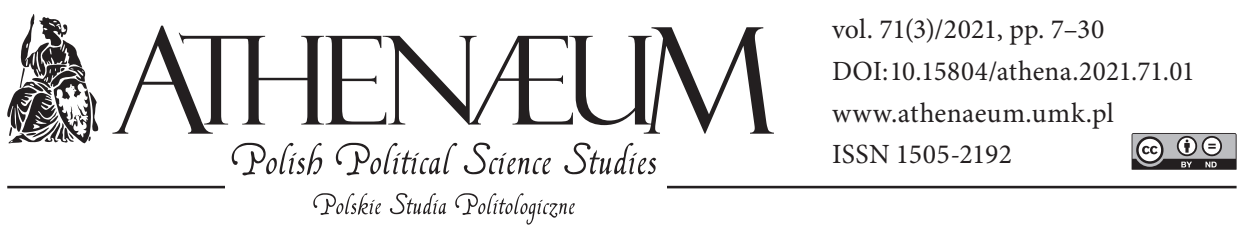

\title{
CATALAN NATIONALISM: BETWEEN CONSTRUCTED CULTURAL MEMORY AND POPULIST STORYTELLING
}

\author{
KATALOŃSKI NACJONALIZM - POMIĘDZY KONSTRUOWANA \\ PAMIĘCIĄ KULTUROWA A RETORYKĄ POPULISTYCZNA
}

Anna Llanos-Antczak* $\odot$

\begin{abstract}
Spain is one of the countries which is facing a lot of nationalist sentiments and aspirations of certain autonomous communities seeking if not for sovereignty, then at least for greater autonomy or a federal system. This paper aims at investigating the case of Catalonia by examining the roots of Catalan nationalism, its main determinants and drivers for change. It also explains the reasons for evolution of the accompanying factors and claims that Catalan nationalism is civic and not ethnic in nature. Its main factors are economic and cultural as well as ideological ones, built on the common identity shaped by cultural and religious heritage. Till the crisis of 2007/2008, Catalan nationalism was not violent - neither in actions nor in its claims. Deterioration of the economic situation and social frustration made it easier for politicians to use the nationalist argument to win a political battle. It resulted in the revival of
\end{abstract}

Hiszpania jest jednym z krajów, które borykają się $\mathrm{z}$ wieloma nacjonalistycznymi nastrojami i aspiracjami niektórych wspólnot autonomicznych, dążących jeśli nie do suwerenności, to przynajmniej do większej autonomii lub systemu federalnego. Niniejszy artykuł ma na celu zbadanie przypadku Katalonii poprzez analizę korzeni nacjonalizmu katalońskiego, jego głównych przyczyn i bodźców do zmian. Wyjaśnia on również uwarunkowania ewolucji czynników mu towarzyszących i stara się udowodnić, że nacjonalizm kataloński ma charakter obywatelski, nie zaś etniczny. Jego główne bodźce to czynniki ekonomiczne i kulturowe, a także ideologiczne, zbudowane na wspólnej tożsamości kształtowanej przez dziedzictwo kulturowe i religijne. Aż do kryzysu lat 2007/2008 nacjonalizm kataloński nie był agresywny ani w działaniach, ani w roszczeniach. Pogorszenie się sytuacji gospodarczej i frustracja

* University of Economics and Human Sciences in Warsaw. 
stronger nationalist sentiments and a desire for self-determination.

Keywords: Catalonia; Spain; nationalism; ideology; Catalan language; culture społeczna ułatwiły politykom wykorzystanie argumentu nacjonalistycznego do wygrania bitwy politycznej. Spowodowało to odrodzenie silniejszych nastrojów nacjonalistycznych i chęci samostanowienia.

Słowa kluczowe: Katalonia; Hiszpania; nacjonalizm; ideologia; język kataloński; kultura

\section{HISTORICAL DETERMINANTS OF CATALAN NATIONALISM}

The issue of nationalism and aspirations of stateless nations for sovereignty or greater autonomy has been long researched, as they became one of the most fascinating and also dangerous problems in international relations at the end of the $20^{\text {th }}$ and continuing in the $21^{\text {st }}$ century. In Europe, they are of special interest and concern, as they are often difficult to tackle in the complicated processes of European integration and often clashing interests of countries involved. Spain is one of the countries which is facing a lot of nationalist sentiments and aspirations of certain autonomous communities if not for sovereignty, then at least for greater autonomy or a federal system (García, 2013; Oskam, 2014; Tortella et al., 2016). This paper aims at investigating the case of Catalonia by examining the roots of Catalan nationalism and its main determinants. It also explains the reasons for evolution of its driving forces, and claims that Catalan nationalism is civic and not ethnic in nature. Its main factors are economic and cultural as well as ideological ones, built on the common identity shaped by cultural and religious heritage. Till the crisis of 2007/2008, Catalan nationalism was not violent neither in actions nor in its claims. Deterioration of the economic situation and social frustration made it easier for politicians to use the nationalist argument to win the political battle. It resulted in the revival of stronger nationalist sentiments and a desire for self-determination.

From the $8^{\text {th }}$ century, Catalonia was under Arab rule, and liberated by the army of Charlemagne, was gradually (until the mid- $12^{\text {th }}$ century) united by the County of Barcelona (monarchy). In 988, the Earl of Barcelona freed himself from the feudal ties connecting him with France. From 1137, Catalonia was tied by union with the Kingdom of Aragon, which became a trading power in the Mediterranean. From 1469, Aragon reunited with Castile, resulting in 
the creation of a dynastic confederation, and in 1516, they both gave rise to the united kingdom of Spain. During the reign of Charles V (1519-1556), it was attached to his empire. In 1640, the autonomous Republic of Catalonia was founded under the protectorate of France, and from that moment (although also earlier), even as a part of a united Spain, it had separate privileges (until 1714), its own institutions, including Cortes - as the legislative authority, and Generalitat ${ }^{1}$ (also existing today) - as executive power. These authorities created their own laws, decided on taxes, and Catalonia was not required to assist the armed forces of the monarchy, except in the event of a direct attack on its territory (Tuñon de Lara, Valdeón Baruque, \& Domínguez Ortiz, 2003).

Beginning with the Middle Ages, Catalonia was the most developed country in Christian Spain, both in economic and civilizational terms, and above all in culture (literature, architecture, painting, philosophy). It was also the time when the national identity of the Catalans began to shape, after breaking the bonds with the King of the Franks. At that time, Catalonia existed as an individual territory under specific jurisdiction, having its own language and culture. Catalan nationalists often claim that there was a Catalan national state in medieval times. However, this is not the right approach, because at that time such a form did not exist at all, and Catalonia, like other European countries, was a principality that determined the form of government itself, although it depended to various degrees on external conditions (foreign monarchies, nations, religion, economy). The issue that distinguishes Catalonia is the preservation of the concept of "divided sovereignty" till the modern times, despite the influence of the absolutism of the monarchical period and later - the liberal trend of nation-state formation. From the earliest times, Catalan political and diplomatic practice was implemented through negotiations that shunned fierce disputes, which is why Catalan nationalism never ${ }^{2}$ took the form of separatism (as in the aspirations of Basques) or became an inspiration for the creation of a terrorist organization as it was the case of ETA in the Basque Country (Giner, 1984, 1996). Catalans were also not exposed to absolutism or unilateralism, because in Catalonia the prerogatives of the monarchical state were very much limited by tradition.

1 It can be translated as 'general council' (Generality). It had (and has) similar competences to the local government and is headed by the president.

2 The situation started changing in 2009 due to controversies over the new Autonomy Statute of Catalonia. 
Moreover, public life was dominated by civil and economic spirit and structures to a far greater extent than the religious or military ones (Antczak, 2008).

Starting from the $17^{\text {th }}$ century, the Spanish monarchy sought all possible ways to limit Catalan autonomy, pursuing to establish a unified and centralized kingdom modeled on a French one. One of the important factors deepening the Catalan-Spanish antagonism was the early and rapidly progressing industrialization and modernization of Catalonia ${ }^{3}$, which to a large extent abolished the discrepancy in technical and economic progress and development between urban and rural as well as highland and lowland areas. This contributed to an even greater consolidation of the Catalan people.

Catalans, being a conservative and deeply religious society, preserved a peculiar political duality: they looked for opportunities to play an important role in Spain, and when this failed due to their inability to defeat the agrarian-military "coalition", they began to strive for autonomy. Thus, it was the time when a contradiction of the idea of the so-called 'Catalanism' was born - it was modern and regressive, progressive and repressive, striving for autonomy and looking for dependency at the same time (Keating, 2001a; Smith, 2014).

The turning point for Catalan nationalism of the $20^{\text {th }}$ century was the creation of a separate and independent system of political parties of Catalonia ${ }^{4}$ in 1901. Then, in 1906, customs barriers were introduced to protect the Catalan textile market and in 1914, Catalonia established the so-called Mancomunitat - a form of its own independent government, quite weak but sufficient to gather the forces of the four Catalan provinces and act on behalf of Catalonia as a unity. Thanks to Mancomunitat, the Catalan language was revived, and various economic and cultural institutions were created.

Catalonia became one of the most difficult problems of the Second Republic (1931-1939). Nationalists supported the idea of overthrowing the monarchy (they wanted to remove King Alfonso XIII de Bourbon from the throne bearing in mind that they were deprived of autonomous privileges by this dynasty) and used this opportunity to win the autonomy statute in $1932^{5}$, at the same time restoring

${ }^{3}$ Apart from the Basque Country, Catalonia was the fastest developing region of Spain at that time.

${ }^{4}$ Until then, in Catalonia (as in other regions of Spain), there was a system of dependence and a kind of despotism (the so-called caciquismo) based on the domination of the head of the local party. The person (or several people) who had the greatest influence in the region also ruled political parties.

${ }^{5}$ It had a short and turbulent history - it was abolished during the right-wing governments (1934-1936), when, fearing for the stability of the Republic and Catalan autonomy, President Lluís 
the Generalitat. It was a kind of a compromise between Catalan nationalists, demanding the creation of a Catalan republic within the (non-existent) Iberian federation, and Madrid republicans (Keating, 2001a). Ultimately, the idea of an integral state - "Estado Integral" (a united state of the regions) - turned out to be victorious. It can be characterized as a quasi-federal system in which the regions could strive for full autonomy after a very long procedure, which was supposed to discourage other regions that would like to follow the three historical lands (the Basque Country, Catalonia, and Galicia).

Nevertheless, the separatist aspirations of national minorities, together with the ideas of democracy, socialism and anti-clericalism, were one of the causes of the General Franco rebellion in 1936. The Generalitat was abolished and its leaders murdered or forced to emigrate. Castilian became the only official language and republican authorities in exile were weak and in conflict with each other. The economic expansion of the sixties brought Catalonia a wave of immigrants from poorer parts of Spain, mainly Andalusia, which caused about $40 \%$ of Catalonia's population to be born abroad at that time. The migrants differed in terms of social and economic status, culture, language, which meant that most of them did not identify with the Catalans. This was not only the case of Catalonia, but also of other prosperous regions, i.e., the Basque Country, and later Valencia and Aragon. The differences between the populations living in individual regions were too great for easy and quick assimilation. As a result, the Francoist idea of "mixing the minorities", which was aimed to blur the differences between them, had the opposite effect - an increase in national consciousness and consolidation. It united all Catalans as opponents of the Franco regime. The extreme left and conservative Catholics fought together to restore democracy, which meant refurbishing the power of autonomy.

In Catalonia, which was geographically closest to democratic countries, the reconstruction of civil society was somewhat different than in other regions of Spain ${ }^{6}$. After Franco's death in 1975, the government of Adolfo Suárez brought back to the country (from exile) in October 1977 the former Catalan President ${ }^{7}$

Companys proclaimed the Catalan state as a part of the Spanish republic. The autonomy statute was suspended together with the Catalan government (i.e., the Generalitat). Later, along with the general elections in February 1936, the Generalitat regained its powers and when civil war broke out, it had such broad powers that it functioned almost as the executive power of an independent state.

${ }^{6}$ More on Franko's times and the early transformation period see: Colomer (1986).

7 From the Times of the II Republic. 
Josep Tarradellas and cast him as a chairman of the restored Generalitat (Fossas \& Colomé, 1993). In 1979, a new Autonomy Statute of Catalonia was signed, which was supported by $88 \%$ of the voting population of the region in a referendum. The first free elections that took place in 1980 were won by Jordi Pujol's united right-wing party Convergència i Unió ${ }^{8}(\mathrm{CiU})$, a coalition of moderate nationalists from the Christian-democratic and liberal party.

Unlike in the Basque Country and taking into consideration the antagonism between Catalonia and Castile, the procedure for granting Catalonia an autonomy statute went smoothly and peacefully. Despite the fact that the Catalans were skeptical about the restoration of the monarchy and the king of the Bourbon dynasty, they considered the stabilization of the newly created democracy as the most important, considering a priority to sign as soon as possible the autonomy statute modeled on the one from 1932 and to have a consent upon the fact that the Catalan side in negotiations with the central government should be represented by Josep Tarradellas ${ }^{9}$. As soon as these demands were met, the Catalans immediately began to benefit from the new situation (their own government, development of education, culture, including language and economy), without seeking to change it and expand autonomy, as it was the case with the Basque Country. In fact, the whole society and its political representatives had a similar vision of how autonomy should look like and what its entitlements should be (Guibernau, 2003). Leading Catalan politicians noticed a number of correlations between the process of democratization of Spain and the creation of well-functioning Catalan autonomy, and therefore they did not make demands for independence that irreversibly undermined Spanish democracy and might even provoke a military coup.

\section{THE FORMATION OF NATIONALIST IDEOLOGY}

In the case of Catalonia, the factors affecting the formation of nationalisms are primarily: cultural complexity, economic development and the way the state is organized. Catalan nationalism is largely based on a wide range of traditions with a diverse social base. The right-wing vision of Catalonia was discredited before

\footnotetext{
8 Convergence and Union.

9 During the Franko's dictatorship he was in exile, and for the Catalans he was a symbol of former independence and the personification of hope for rebuilding their autonomy.
} 
the civil war and eventually collapsed during the Francoist era, because it was against the reconstruction of the national identity of Catalonia. The conservative and centralist $\mathrm{PP}^{10}$ is perceived as anti-Catalan. This means that traditionalism and social paternalism, combined with the ideology of the Catholic religion, were closely related to Catalan nationalism and its ideology, and thus also to the ideological basis of the CiU party.

The socialists $\left(\mathrm{PSC}^{11}\right)$ and Catalan communists $\left(\mathrm{IC}^{12}\right)$ were cautious about nationality issues, but also supported the idea of the region's autonomy, accusing Pujol of monopolizing Catalan nationalism. Nationalist movements were also supported by Christian democracy (a political movement that was established successfully only in Catalonia and the Basque Country, where Catholicism served to unite the nation).

The above analysis shows that Catalan nationalism had its supporters in all socio-political formations, and although it was always strongly associated with the sharing of a common national identity, history, culture and language, not all Catalans would gladly define themselves as nationalists. It is extremely interesting, however, that the cultural identity of Catalonia has always contained a political element (Prat de la Riba, 1987). Individual political groups differed in their approach to immigrants, but thanks to Jordi Pujol, the idea of assimilation spread so that visitors, by learning culture and language, would be able to share the same story in the future. It facilitated immigrants, who came mainly from the working class, social and economic advancement after some time. Pujol's definition of who can be considered Catalan reads as follows: "Everyone who lives and works in Catalonia and wants this situation to continue and feels connected to this land is Catalan" (Mercadé, 1982, p. 153).

It seems important that strong nationalism is close to all social groups and political formations of Catalonia. Contrary to the Basque Country, the support for separatist aspirations was always rather weak (till the second decade of the $21^{\text {st }}$ century). Such an idea was not taken into account at all in the $19^{\text {th }}$ century, it spread to a small extent and for a short time during the civil war for tactical, more

\footnotetext{
10 PP - Partido Popular (People's Party).

11 PSC - Partit dels Socialistes de Catalunya (Catalan Socialist Party) - regional equivalent of the PSOE: Partido Socialista Obrero Español (Spanish Socialist Workers' Party).

12 IC - Iniciativa per Catalunya (Initiative for Catalonia) - regional part of the IU: Izquierda Unida (United Left).
} 
than ideological reasons, because Barcelona was cut off from Madrid ${ }^{13}$. From that moment, a small group of separatists promoting the so-called pan-Catalan policy wanted to unite all regions with Catalan roots, including Roussillon, Andorra, Balearic Islands, and Valencia. An even smaller group formed the Terra Lliure armed faction, which for a short time cooperated with the Basque ETA, organizing joint terrorist operations. Members of this movement ceased military operations and became involved in politics at the beginning of the nineties of the $20^{\text {th }}$ century. In 1992, the Republican Left $\left(\mathrm{ERC}^{14}\right)$ postulated independence ideas, but with the arrival of the era of transformation in Europe towards a federation of nations, it gave up these aspirations. Despite the weak support for separatist ideas, all parties, except the extreme right, accept the right to self-determination of Catalonia, treating the relationship with Spain as a complex situation, created on the basis of the free choice of both sides, which means for Catalonia much more than granting the status of an "ordinary" region".

Inspired by international restoration, the Catalan Parliament adopted on December 12, 1989 a request ${ }^{16}$ for the right of the Catalan people to selfdetermination ${ }^{17}$. Pujol, supporting this resolution assured however that Catalonia could only exist in harmony and unity with Spain, which was a kind of paradox. A certain inconsistency, even a contradiction, is the own perception of the Catalans who have always considered themselves the most European of all regions of Spain and better suited to other societies of the European Union in economic, social and political terms. There are contradictions when juxtaposing such reasoning with their eternal pursuit of protecting their own market

13 During the civil war, the government first moved from Madrid to Valencia and then to Barcelona. In December 1938, General Franco's nationalists gradually began to occupy the whole Catalonia; the government moved to Figueres, and then wandered between Valencia and Madrid. In this way, Catalonia was overrun by right-wing nationalists, cut off from Madrid, which was still republican and fighting against Franco.

14 ERC - Esquerra Republicana de Catalunya (Catalan Republican Left).

15 This was rooted in the system that functioned before 1714, when Catalonia had its own government, operating within the Spanish confederation and being embedded in a broader Mediterranean and European context. This allowed Catalonia to play an important role in shaping Spain's national policy. For more see: Payne (1991).

16 The applicant was the Catalan Republican Left (ERC).

17 Point 2 reads as follows: "[...] Despite the political transformation and transition from dictatorship to democracy, it does not mean the resignation of the Catalan people from the right to self-determination and creating the basis for functioning in an international environment. [...]" - Resolució 98/II del Parlament de Catalunya, sobre el dret d'autodeterminació de la nació catalana - Buletí Oficial del Parlament de Catalunya, 18 December 1989, No 120. 
and establishing customs barriers. The only solution turned out to be European integration within the EU and the free trade area. The European Union has also become a stage on which Catalans could realize their European aspirations and opportunities to develop their autonomy. The slogan created by the CiU, which was adopted by Catalan society: “Catalunya, un País d'Europa” [Catalonia, a European Country], confirms the aspirations of the region and the pursuit of ever-increasing autonomy. The accusation against nationalists of not specifying the final point to which they strive in their actions is repulsed by the statement that the point to which integrated Europe is heading has not been specified either, and both these matters are closely related. Slow disillusionment in the EU and lack of further perspectives as well as the global economic recession together with the internal situation related to the new Autonomy Statute resulted in dissemination of separatist ideas in the second decade of the $21^{\text {st }}$ century.

If one analyzes the political programs of Catalonia's major political parties, it would turn out that the differences in nationalist approaches were not fundamental. The most important seems to be the fact that they all treated Catalans as a separate nation and not a national minority or an ethnic group motivating it with centuries-old history and territorial cohesion, a separate culture, language, as well as legal, administrative and social system, which influenced the sense of national identity and creation of own quasi-state institutions and structures.

\section{FACTORS SHAPING CATALAN NATIONALISM DURING THE TRANSFORMATION PERIOD, IN THE $1990 \mathrm{~S}$ AND IN THE 21ST CENTURY}

Catalans do not treat the concept of state as a purely historical fact. According to them, the most important element is the process of building national consciousness, which strengthens cultural bonds and national identity, which is expressed by building own state and government ${ }^{18}$. The Spanish transformation from the authoritarian system to democratic and subsequent integration with the European Communities resulted in an increase in the national consciousness of Catalans (Keating, 2001a). At the early transformation and in the 1990s, the people who considered themselves exclusively Catalans were mainly the generation who still remembered the pre-Francoist era or young people. Those who only

18 More on shaping Catalan politics see: Pujol $(1976,1980,1996)$. 
identified with Spain were almost exclusively uneducated immigrants, although some people born outside of Catalonia declared Catalan or dual identity (Keating, 2001a). This means that assimilation (or lack of it) had a greater impact on national beliefs than the place of birth or parental origin, although Catalan origin most often determined national identity. This, of course, translates into political sympathies - people declaring the strongest relationship with Catalonia identified with the ERC and CiU, and supporters of Spain - mainly with the PP and PSC, as national parties (although PSC as much as IC enjoyed the greatest support of these who perceive themselves as both Catalans and Spaniards).

Studies conducted by the Institute of Political and Social Sciences in Barcelona at the beginning of the $21^{\text {st }}$ century show that just over half of the inhabitants of Catalonia identified with the concept of nationalism. Catalans were very hesitant about their attitude towards autonomy and independence, as there were the same number of supporters of Catalonia's independence as opponents (approx. 30\%). The main aspiration of the Catalans was political autonomy based on building of strong social awareness that is associated with language, culture, economic and foreign policy as well as the civil society. The situation started changing in 2007 - the reason for the increase in separatist sentiments was the economy, the desire to have a greater control over the financial issues and political and economic decisions related to the region especially in the times of global recession. The peak desires for independence were related to the issues of the new Autonomy Statute (more than $40 \%$ of population opted for independence) and this resulted in social unrests. Still, Catalan nationalists do not opt for ethnic unity or "purity", which means that Catalan nationalism is not ethnic, as in the Basque Country, but rather civil in nature.

In the early 1990s, postulates for sovereignty were revived, inspired by the example of the Baltic States and caused by the celebration of the tenth anniversary of Catalonia's statute of autonomy. This resulted in Pujol's numerous speeches on the weakness of autonomous structures and the need to verify them, as well as suggestions that Catalans have the same right to self-determination as the nations of the republics that made up the USSR, bearing in mind at the same time the negative effects of such aspirations that took place in Yugoslavia. Most Catalans also believed that the central government favored some autonomies instead of treating them all in the same way. 


\section{LANGUAGE AND CULTURAL CONSTRUCTS}

Similarly to the Basque Country, in Catalonia language and culture (which were particularly emphasized in the last years of the $19^{\text {th }}$ century) became the carrier of national identity guaranteeing the survival of the community. It can be claimed that from 1714 (when Catalonia was deprived of autonomy) until the reconstruction of the democratic system in Spain in the second half of the 1970s, Catalonia was subjected to forced assimilation with Spain (and thus it was necessary to use Castilian language). During General Franco's dictatorship, all minority languages, including Catalan, were banned, and education was delivered only in Castilian, which was also the language of the entire administration, the judiciary, the army and the business world. Since the reconstruction of the Generalitat, Catalans have sought to create a standardized Catalan language, which was a part of the plan to rebuild national identity and the possibility of gaining wider influence in Europe as a full-fledged nation (Keating, 2001b).

On the one hand, the language was to be a determinant of national identity, and on the other - it was not supposed to be a factor building a barrier between the native Catalans and the immigrant population. This is another confirmation of the thesis that Catalan nationalism has no strong ethnic element (as it is in the case of the Basque Country), only civic and territorial one. Therefore, the lack of permission for Catalonia's bilingualism resulted from the desire to avoid social divisions. During the transition period, the most important thing was the introduction of the Catalan language into the education and administration system, and then into the economic sphere. However, the basic law normalizing matters of official languages in Catalonia - "Llei de Normalització Lingüística a Catalunya" of 1983 - states that the official languages of the autonomy are Catalan and Castilian on an equal footing. As far as education is concerned, the law provides that students have the right to choose the leading language of education but must achieve a level of proficiency in both official languages.

Cultural constructs are even more important for building up Catalan identity and nationalism. Legends, icons, people, events - all these build an impressive inventory and constitute Catalan collective memory, which is very helpful to posit a significant political heritage. Catalans pay a lot of attention to their cultural heritage and legendary heroes, as well as mythic figures. Their historical memory is built on the mixture of legends, national heroes, saint patrons and important historic events - e.g., Wilfred the Hairy (Guifré el Pilós, in Catalan), Belló I of Carcassonne, King James I, Rafael Casanova, 
Josep Moragues i Mas, mythic figures like Otger Cataló and Count Arnau (as an antihero), Sant Jordi, Santa Eulalia, and Santa María. As far as the modern culture is concerned, the $19^{\text {th }}$ and $20^{\text {th }}$ centuries were extremely rich in Catalan artists (Joan Miró, Salvador Dalí, Antoni Gaudí, just to enumerate a few, as Catalonia had a lot of them), intellectuals and writers (Mercè Rodoreda i Gurguí, Narcis Monturiol, Salvador Espriu), politicians (Valentí Almirall, Enric Prat de la Riba, Lluís Companys), business leaders (Facundo Bacardí, Enric Bernat, or Eusebi Güell) or even musicians, cinema, theater, and sports people (Jordi Mollà, Jaume Collet-Serra, Montserrat Caballé, Josep Carreras, Pep Guardiola, Pau Gasol, and Arantxa Sánchez Vicario) who strongly contributed to develop even more profoundly the Catalan identity (Vargas, 2018; Balcells, 1996; Casanovas, Corretger, \& Salvador, 2019). As claimed by Vargas (2018), they "embellished the folklore and traditions, promulgated the history and myths and built up the physical infrastructure recognized as distinctly Catalan". Catalan identity is also built around many traditional symbols, many of which originating from the folklore, as the sardana dance, the Castellers (human towers in town squares), red peasant caps. The mountain of Montserrat and its monastery of Santa Maria is a symbol of Catalonia, the essential element of its religious and spiritual heritage and one of the most visited places in Europe by tourists. Catalans build their identity also through introducing into international tourism the spirit of their culture with the splendorous Barcelona being its center, but also being proud with the coasts, nature, sports and even regional products. It is also interesting to mention that the football club Barça is perceived as a repository of Catalan cultural memory.

\section{ECONOMIC SITUATION}

Catalonia, along with the Basque Country, was the region that industrialized the fastest, and for this reason there was a conviction (which continues to the present day) that it was being used by Spain and that the region was working to support the rest of the country. However, this situation was not the result of a good economic structure or competitiveness of the goods offered. Catalonia's success was based on thriving family businesses which possessed their own capital based on savings and the fact that protectionism prevailed on the Spanish market for a long time (Viu, 1998). Catalonia's favorable geographic position and entrepreneurial spirit of its inhabitants also helped to achieve prosperity. 
Spain's access to the EEC resulted in full participation in a competitive European market with all the consequences. Adaptation of the Catalan economy to European standards had become a priority for some time. It was also about the takeover by the Catalan regional authorities of the part of the economy, which in Franco's times was directed towards Madrid, as well as the foreign capital. One of Pujol's initiatives ${ }^{19}$ was the creation of the Catalan Bank in 1959, which would allow the financing of Catalan industry and investments (Baiges, Gonzalez, \& Reixach, 1985). As a result, the bank became a kind of a center of Catalan identity, as it also financed all cultural, integrational and political initiatives.

The structure of Catalan enterprises is dominated by small enterprises (43\% of them employs less than a hundred employees), though paradoxically, it is Catalonia that has the largest number of large enterprises (over five hundred employees), which also reflects the share of foreign capital and the number of international companies (Keating, 2001a). In the case of trade, Catalonia is very internationalized with a continuous upward trend in this direction, but still remains dependent on Spain. Consequently, Catalonia is far from restoring its position as a European trade tycoon.

The economic policy pursued by the Generalitat obviously aims to restore the economic power of Catalonia. As claimed by Keating (2001a), different political parties have diverse ideas on how to achieve this, but agree on the need to improve the competitiveness of Catalan economy so that it had equal chances with other European economies by:

- internationalization;

- promotion of exports;

- foreign investment;

- maintaining the balance between foreign investments and own investments abroad;

- stimulation of the importance of Catalan industry in Europe, in particular in the Mediterranean;

- research, development and technology transfer;

- creating own sources of financing the economy;

- development of small enterprises.

The autonomous government does not control most social policy instruments, which prevents it from balancing economic development-oriented policies with social justice that is typical of a protective state. All the factors discussed above

${ }^{19}$ It was supposed to strengthen his nationalist policy. 
prove that the road to rebuilding the Catalan economy, modeled on the $19^{\text {th }}$ century power, was long and complicated, and there is still a lot of work to do.

A characteristic feature of Catalan nationalism was the lack of political guiding force (as in the case of the Basque $\mathrm{PNV}^{20}$ or even the extremist $\mathrm{HB}^{21}$ ) and a specific 'pactism' (till the crisis of 2009/2010). The idea of greater autonomy for Catalonia was supported by all political parties and groups representing the interests of almost all social groups (even the immigrant population, which mostly assimilates, as this is the only way allowing for social advancement), and for most of the time, there were few supporters of full sovereignty of Catalonia. The rich middle class, which is a solid base of the Catalan society, exploiting economic prosperity, is not interested in separation but in political and economic stability under favorable autonomy (Bernatowicz, 1992). The reason for this situation is that $16 \%$ of Spain's population live in Catalonia, and it produces: $25.6 \%$ of Spain's exports, $19 \%$ of Spain's GDP (and in the previous years before the crisis, it was much more) and $20.7 \%$ of foreign investment. The important thing is that nationalism in Catalonia has always had the support of the Catalan Catholic church (Astor, 2020). Economy as one of the driving forces of the recent independence movements was a direct result of the global crisis that concerned also Catalonia, where the unemployment rate rose from $7.5 \%$ to 23.6\% between 2006 and 2011, while the Catalan contribution to Spain's gross domestic product (GDP) declined from $25.6 \%$ in 1979 to $19 \%$ in 2010 and the regional government faced severe liquidity problems (Dowling, 2014). Economic recession caused a significant change in the Catalan society's perception towards independence (Conversi \& Jeram, 2017) which was perceived as a cure for the worsening state of affairs.

\section{FOREIGN POLICY AND AUTONOMY STATUTE REFORM}

The Generalitat set itself as one of the main goals to promote exports. Given that Catalonia has strong links with France and the Mediterranean region, entering European markets was definitely less of a problem than entering global markets. Conducting an effective economic, social and cultural policy is the main goal

\footnotetext{
20 Partio Nacionalista Vasco - Basque National Party.

21 Herri Batasuna - One Nation/Popular Unity - there are different translations from the Basque language, called 'euskera'. It was a political arm of ETA terrorist organization.
} 
of foreign policy pursued by Catalonia, which aims to mark its national identity (similarly to the Basque Country).

As for the European Union is concerned, the main factor connecting it with Catalonia is the economy. As early as 1982, the Patronat [Patronage] Català Pro Europa was established, a body that was to disseminate information about the EU before Spain's accession to the EU, to prepare Catalonia and find the best ways of integration that would bring benefits. Given that the so-called stateless nations have no impact on the EU policy, Catalan authorities wanted to closely cooperate with Spain in this field, supporting its activities. Catalonia did not have such aspirations as to the role it was to play in the EU as the Basque Country. However, it was seeking a clause in the Maastricht Treaty, which would allow the autonomous government to represent Catalonia in external relations. The Catalan government willingly signed agreements with other regions, and in 1991 it participated in the creation of the Euroregion of the Central Pyrenees and Languedoc-Roussillon, which was to promote cooperation in the areas of communication, business development, education and professional development, agriculture, culture and sport, and environmental protection. There are many cooperation groups between the border regions of Spain and France, as well as cooperation in the framework of the partnership of the four so-called "Motors of Europe": Catalonia, the Rhône Valley-French Alps region, Lombardy, and BadenWürttemberg. Although Catalonia is inferior to the rest in terms of technological advances, it benefits from prestigious and marketing profits, which allows it to control the decision-making system at the national level and even to have some influence on the revision of the treaties. Catalonia plays a huge and a kind of a model role in the Committee of the Regions and has become a model for other stateless nations.

The Mediterranean is a very important region for Catalonia, and it has always been in its greatest interest (Ferrater Mora, 1987). For this reason, Catalonia signed many cooperation agreements with the Maghreb countries, mainly in the field of tourism, forestry and other areas of economic development. This is to encourage Catalan entrepreneurs to invest in North Africa and at the same time strive to curtail economic immigration from these countries to Catalonia (of course, immigrants also come to other regions such as Valencia, Andalusia, and Madrid ${ }^{22}$. In addition, as mentioned by Petschen (1992), Catalonia also has

22 At the beginning of the 1990s, Spain started to receive mass immigration from the Maghreb countries (mainly from Morocco). Initially, it enveloped Madrid, the Canary Islands, then the Balearic 
cooperation agreements with Argentina and the state of Ilinois and established contact with the World Bank, the International Monetary Fund and financial institutions in Europe (mainly in London, recognized as Europe's financial center). Catalonia pays a lot of attention to cultural policy and to the promotion of Catalan culture and language through university and national programs. After pressure put on the European Parliament, there arose interest in minority languages and the symbolic effect was the recognition of Catalan as a European language in 1990. Catalans hoped that this would be an introduction to the recognition of Catalan as the official language of the Parliament (as it was the case with the Irish language). However, the European Parliament still treats Catalan as a working language and not as one of the languages of debates and simultaneous translations. All these efforts are aimed at promoting the region not as one of the provinces of Spain, but as a separate autonomy, as evidenced by ads in American newspapers before the Olympic Games in 1992: "Where is Barcelona?", and the correct answer was to be "in Catalonia" and not "in Spain". This commercial was intensified by Pujol's numerous travels around Europe and the Americas. However, despite all such efforts, the Catalan government declared that it was not intended to promote the region as competitive or alternative to Spain.

The Generalitat is not the only body that conducts Catalonia's external policy. A foreign affairs directorate was created for these purposes under the authority of the President of the Generalitat, which is to coordinate and give direction to Catalan external policy. However, the executive power is in the hands of relevant agencies, departments and chambers of commerce of the public and private sectors. Catalonia has about thirty representation agencies abroad, mainly in Europe, but also in New York, San Francisco, Tokyo, and the Maghreb countries. However, they do not represent the government, they are run by private individuals, highly qualified mainly in the field of economics and the public sector's contribution is minor. These representations also include Consorci de Promoció Comercial [Consortium for Trade Promotion] and Consorci de Projecció Exterior de la Cultura Catalana [Consortium for Foreign Promotion of Catalan Culture], as well as the pro-European Patronat Català pro Europa. Their tasks focus mainly on areas such as promotion of tourism, foreign investment and culture, and assistance in implementing export contracts.

Islands, but later also expanded to Catalonia and the rich regions of Valencia, Murcia, and also Andalusia (mainly around seaside resorts). 
The authorities in Madrid raised a number of reservations regarding Catalonia's right to engage in foreign policy and sign agreements with regions outside Spain. However, in 1993, the Constitutional Court recognized Catalonia's right to pursue an independent external policy to the extent that it concerned its interests. In other words, Catalonia has competence that relates directly to this region. In reality, however, the CiU's strong position in the Spanish government after the 1993 and 1996 elections (and only slightly weakened in 2000 and 2004, but remained quite strong till the dissolution in 2015 due to disagreements between two constituent parties, CDC and UDC, on the independence issues), as well as the participation of Catalan parties (similarly to Basque ones) in international groupings turned out to be much more important. However, after the change of the central government, Prime Minister José Luis Rodríguez Zapatero, in numerous public appearances regarding the possible reform of the Autonomy Statute of Catalonia, spoke favorably of this concept, to the extent that he was inclined to recognize Catalonia as a separate nation. On September 30, 2005, the Catalan Parliament adopted ${ }^{23}$ a proposal of the Autonomy Statute of Catalonia reform. First of all, the new (third) statute introduced in the preamble the terms "nation" and "state" 24 in relation to Catalonia and its inhabitants. Art. 6 of the Statute states that the official language in Catalonia is Catalan and Castilian, as the national language of the Spanish state. The national symbols of Catalonia are its own flag, anthem and national holidays, which is enshrined in Art. 8 of the document. The new statute gave Catalonia greater rights and competences regarding policy-making towards the European Union (including the right to participate in some decision-making processes regarding Spain's policy towards the EU). The statute also established the right for the region to collect all taxes paid in Catalonia and to transfer to Madrid as much as the regional authorities deem appropriate. The document gave Catalonia exclusive competence in the judiciary, banking, social security, education matters and management of ports and airports. It also included the right of Catalans to change Spanish laws and established relations between Catalonia and Spain as if they were two separate states. A proposal of the Autonomy Statute of Catalonia reform was presented and discussed at the Congress of Deputies on November 4, 2005 and was addressed to

23 With 120 votes in favor and 15 (the PP deputies) against.

24 The preamble states: "Cataluña es una nación" [Catalonia is a nation] and "Cataluña es un país..." [Catalonia is a state] (Propuesta de Reforma de Estatuto de Autonomía, 2005). 
the Constitutional Committee for amendments ${ }^{25}$. Surveys commissioned by the Generalitat showed that the proposal to reform the statute enjoyed widespread public support in Catalonia (71.4\%), and beyond the project was criticized by almost half of those surveyed.

In December 2005, the Constitutional Court issued its opinion, in which the most important statement was related to the term "nation", which it considered inappropriate and suggested a change to "nationality", or the use of general terms such as Catalonia or Catalans. On January 22, 2006, José Luis Rodríguez Zapatero, president of the Generalitat Pasqual Maragall and representatives of the $\mathrm{CiU}$ came to an agreement that the term "nation" would remain in the preamble of the Statute as a descriptive but not defining term. This text was approved by the Constitutional Commission of the Congress of Deputies on March 21, 2006. Regarding the financial policy, it was agreed that Catalonia would pay Madrid 33-50\% of personal income tax. This solution satisfied both Catalans and the central government. Moreover, beginning in the 1990s, CiU (together with the Basque PNV and Galician Nationalist Bloc) insisted on constitutional reform seeking to create a federation and recognize Spain as a multinational state. Finally, in June 2010, the Constitutional Court of Spain declared the 14 articles of the Statute partially or completely unconstitutional (including the ones on the Catalan nationality and the language). This in turn resulted in social unrests and organization of series of informal referenda on independence. A manifestation of protest activity that had never been seen before was the manifestation of September 11, 2012 - the National Day of Catalonia witnessed a manifestation of protest for independence in Barcelona. Catalan political stage also changed significantly. Regional elections of 2012 were won by pro-separatist parties, who proclaimed the Declaration of Sovereignty in 2013 and in 2014 conducted a secession referendum, which was declared illegal by the central government and in which almost $81 \%$ of the voters opted for independence (Lepič, 2017; Cohen, 2011; Rivero, 2015; Hodlevska, 2019). In 2015, Catalans voted again for a pro-separatist coalition "Together for Yes" [Junts pel Sí], and on October 27, 2015, this coalition and the "Candidates for National Unity" agreed on a draft parliamentary resolution on independence. The document announced, "the beginning of the process of creating an independent state of Catalonia in the form

25 On the one hand, the government did not want to agree to any provisions aimed at the almost complete separation of Catalonia from Spain, but on the other hand, it did not want to generate a far-reaching conflict with the autonomous government of Catalonia. 
of a republic" (Resolució 1/XI del Parlament de Catalunya, 2015). In the 2017 referendum, $90 \%$ (out of $43 \%$ of the voters who took part in the vote) opted for the separation of Catalonia (El País, 2017, October 6). The Spanish government made the police to use force police against the voters at polling stations, which resulted in the Catalan unions organizing a general strike, paralyzing the social and economic life of the region. On October 27, 2017, the regional parliament declared independence of Catalonia. In response, the Cortes Generales voted to apply the $155^{\text {th }}$ article of the Constitution, which allowed the regional authorities of Catalonia to be removed from the government, to introduce direct control from Madrid, and to announce early parliamentary elections in Catalonia. On November 3, 2017, eight members of the Catalan government were arrested by the Spanish authorities, the next day an international arrest warrant was issued for the President of the Generality of Catalonia, Carles Puigdemont. On December 21, 2017, central government announced early elections to the Catalan parliament, as a result of which an absolute majority remained with the block of the supporters of independence of the region (47.5\%). On October 14, 2019, nine of the Catalan independence leaders were sentenced to between nine and thirteen years of prison, which provoked protest and demonstrations especially in Barcelona, which became violent after the use of force of the Spanish police.

\section{CONCLUSIONS}

The analysis of the phenomenon of Catalan nationalism clearly shows that the pursuit of greater autonomy has not been as saturated with separatist aspirations as it was the case in the Basque Country till the second decade of the $21^{\text {st }}$ century. Peaceful methods dominated, in no way referring neither to violence nor extreme and very advanced demands (except for the short period when Terra Lliure was active, until the early 1990s). Actions aimed at establishing a new Autonomy Statute of Catalonia were an attempt to affirm a separate nationality (finally, it states that Catalans are a nation, i.e., they stand on an equal footing with the Spanish nation). This is due to the unfulfilled aspirations of Catalonia to play the most important role in Spain, to preside and pave the way for the whole country to develop in accordance with the Catalan concept. The economic advancement and prosperity of the region generate a desire to have a greater impact on the shaping of Spain's politics and policies, especially in the economic sphere, and to have the opportunity to influence the matters concerning the European Union. 
The most important role in the case of Catalonia plays the economic aspect. This region, as the richest and most developed in the whole Spain, feels used by the rest of the country. This belief is also rooted in history when Catalonia was deprived of its privileges. However, all these actions were not directed against the Spanish state and did not have the separatist or independence element, and they resulted from the desire to have a stronger position and the right to decide especially in matters directly related to the region. This changed in the second decade of the $21^{\text {st }}$ century when many social, economic and political factors coincided. According to Della Porta et al. (2017), the level of Catalan popular unrest resulted to a large extent from a combination of three root contextual causes (socioeconomic, political, and territorial), which made the crisis spiraled. Guibernau (2013) rightly explains the rise of separatism in the Catalan society and the transition of the conflict between Catalonia and the Spanish state in the active phase by distinguishing three main factors. Firstly, he points out that the government of José María Aznar (2000-2004) did not respond to Catalan demands for greater autonomy at a time when the separation was not even mentioned. Moreover, an important flashpoint was the issue with the Autonomy Statute and its final rejection by the Cortes Generales after it was authorized by the Parliament of Catalonia, as well as by the Catalan people in a referendum. The final issue was raising awareness of the impact of accumulation of an annual deficit of $8 \%$ of Catalonia's GDP in connection with the financial arrangements established by the Spanish state (Guibernau, 2013).

All the above analysis shows that it is not true that Catalan nationalism has always aimed at independence, as claimed by García, and it is clearly visible in the change of the nation's sentiments (Sondeig d'Opinió). It is true however that as in all Europe, nationalist and at the same time populist movements started to grow at the second half of the first decade of the $21^{\text {st }}$ century coinciding with the economic crisis. In Catalonia the same processes happened, which is why separatist sentiments started to be livelier. Storytellers, that is politicians, intellectuals, journalists (García, 2018), found a fertile ground in Catalan society (whose economy declined due to the global financial crisis, whose expectations towards the EU were weakened, and whose disappointment by the behavior of the central government in relation to the new Autonomy Statute was strong), and they only had to carefully and pragmatically select which elements of reality to use. These populist stories related to nationalist sentiments were skillfully connected to national myths and cultural constructs which are very strongly rooted in Catalans' identity. As indicated by Gamper Sachse (2018), "the popular organization 
of the referendum on 1 October 2017 and the vigorous democratic experience by almost half of the population of Catalonia allow for a characterization of this populism as a hybrid phenomenon that includes bottom-up and top-down dynamics, thereby contrasting with the usual leader-centered understanding of populism", and this shows that Catalan society, vulnerable for the stories of their past and sentimental for their cultural heritage, are eager to recall them each time they feel their rights and freedoms are not fully respected. These, skillfully fueled by politicians and other social elites, create a very solid base for more radical nationalism and separatism in Catalonia. Politicians, aiming at gaining social support in the times of populist sentiments, stimulate independence tendencies. They indicate that separation is the only way to solve the Catalan problem while they seem to stay silent on the possible outcomes and consequences (Ovejero, 2018) of Catalonia's separation from Spain (just to enumerate the basic ones: politically - being outside the EU and its money, financially - being out of the common market, and socially - being out of Schengen).

What unifies and guarantees national continuity is language, institutions and history (more in a socio-cultural sense), not the myth of having shared ancestors (it is not ethnic nationalism). Weak separatist aspirations (till 2009/2010) did not mean giving up the desire to have more autonomy in many areas of public life and the desire to promote Catalonia in Europe and the world. There has been a clear tendency to turn more towards the EU (integration with the EU is assessed by the vast majority of Catalans as beneficial) than Madrid, as the forum more suitable to fight for their interests. Jordi Pujol and his supporters saw a great opportunity for Catalonia in the concept of "Europe of regions". This path, at least for some time, must have led through Madrid, because Catalonia (as well as other stateless nations) lacks institutionalization. Most of the time, Catalonia was not as hermetic and radical in its pursuits as the Basque Country, there was no xenophobia and cultivation of the purity of blood. Catalanism is not ethnic but civic in nature. Catalan nationalism is based to a large extent on the constructed memory of historical events, legendary heroes, culture and pride resulting from the fact of having strong cultural heritage. Constructed social pride based on legends and cultural heritage and traditions was also a strong base for politicians after 2009 to build separatist sentiments.

The research of the Institute of Political and Social Sciences in Barcelona and the analysis of events in Catalonia of the last two decades show that the idea of nationalism is supported by wide social circles. At the same time, however, despite the high awareness of a separate national identity, the Catalans did not 
show strong separatist tendencies until 2009/2010. A significant part of society identified with Catalonia as much as with Spain, despite the fact that most of them mentioned Catalonia in the first place. For many years Catalonia did not seek independence, but only affirmation of its own identity, and Spain's acceptance that the Catalans are a separate nation. This also results from the region's aspirations to have greater influence on the shaping of Spain's policy in matters related to the economy and the EU. Catalonia wanted to play a greater role in the political arena in both internal and international affairs, and in these matters, it did not want to act as a "component" of Spain, but wanted to have its own separate voting rights. As it did not happen, on the contrary, the new Autonomous Statute was declared to be unconstitutional by the central government. These actions of the central government coincided also with the economic recession, which made it far easier for the local politicians to play the nationalist card. Proindependence sentiments rose significantly and also the social composition of its supporters changed. Mass mobilization also contributed to triggering a process of polarization that pushed the traditionally moderate Catalan nationalist parties to an increasingly radical stance, as claims moved from autonomy to independence (Della Porta et al., 2017; Della Porta \& Portos, 2021). All that pushed the politicians into easy storytelling based on traditional sentiments and constructed cultural memory without really explaining what independence would mean for Catalonia - politically, economically, and socially.

\section{REFERENCES:}

Antczak, A. (2008). Kształtowanie się tożsamości narodowej wspólnot autonomicznych $w$ Hiszpanii. Warszawa: AON.

Astor, A. (2020). Religion and Counter-State Nationalism in Catalonia. Social Compass, 67(2), 159-176. DOI: 10.1177/0037768619898651.

Baiges, F., Gonzalez, E., \& Reixach, J. (1985). Banca Catalana. Má s que un banco, más que una crisis. Esplugas de Llobregat, Barcelona: Plaza y Janes.

Balcells, A. (1996). Catalan Nationalism: Past and Present. Basingstoke-London: Palgrave MacMillan.

Bernatowicz, G. (1992). Problem mniejszości narodowych w Hiszpanii. Sprawy Międzynarodowe, 45(10), 145-158.

Casanovas, P., Corretger, M., \& Salvador, V. (Eds.) (2019). The Rise of Catalan Identity: Social Commitment and Political Engagement in the Twentieth Century. New York: Springer International Publishing. 
Cohen, Y. (2011). The Spanish: Shadows of Embarrassment (Heritage, Society and National Identity in the European Union). East Sussex, UK: Sussex Academic Press. Colomer, J.M. (1986). Cataluña como cuestión de Estado: La idea de la nación en el pensamiento político catalán, 1939-1979. Madrid: Tecnos.

Conversi, D., \& Jeram, S. (2017). Despite the Crisis: The Resilience of Intercultural Nationalism in Catalonia. International Migration, 55(2), 53-67. DOI: 10.1111/ imig.12323.

Della Porta, D., O'Connor, F.P., Portos García, M., \& Subirats Ribas, A. (2017). Social Movements and Referendums from Below: Direct Democracy in the Neoliberal Crisis. Bristol-Chicago: Policy Press, Bristol University Press.

Della Porta, D., \& Portos, M. (2021). A Bourgeois Story? The Class Basis of Catalan Independentism. Territory, Politics, Governance, 9(3), 391-411. DOI: 10.1080/21622671.2020.1737208.

Dowling, A. (2014). Accounting for the Turn towards Secession in Catalonia. International Journal of Iberian Studies, 27(2-3), 219-234. DOI: 10.1386/ijis.27.2-3.219_1.

Ferrater Mora, J. (1987). Las Formas de la vida catalana. Madrid: Alianza Editorial.

Fossas, E., \& Colomé, G. (1993). Political Parties and Institutions in Catalonia. Barcelona: Institut de Ciències Polítiques i Socials.

Gamper Sachse, D. (2018). Ambivalences of Populism: The Case of Catalan Independentism. Social Science Information sur les Sciences Sociales, 57(4), 573-587. DOI: $10.1177 / 0539018418811685$.

García, C. (2013). Strategic Communication Applied to Nation Building in Spain: The Experience of the Catalan Region. Public Relations Review, 39(5), 558-562. DOI: 10.1016/j.pubrev.2013.07.006.

García, C. (2018). The Power of Myths and Storytelling in Nation Building: The Campaign for the Independence of Catalonia from Spain (2012-2015). Canadian Journal of Communication, 43(2), 281-296. DOI: 10.22230/cjc.2018v43n2a3226.

Giner, S. (1984). The Social Structure of Catalonia. Glasgow: Anglo-Catalan Society.

Giner, S. (1996). La cultura catalana: el sagrat i el profà. Barcelona: Edicions 62.

Guibernau, M. (2003). Nationalism and Intellectuals in Nations without States: The Catalan Case. ICPS Working Papers, 222(03). Barcelona: Institut de Ciències Polítiques i Socials.

Guibernau, M. (2013). Secessionism in Catalonia: After Democracy. Ethnopolitics, 12(4), 368-393. DOI: 10.1080/17449057.2013.843245.

Hodlevska, V. (2019). Catalonia: Endeavor for Independence. European Journal of Transformation Studies, 7(2), 79-94.

Keating, M. (2001a). Nations against the State: The New Politics of Nationalism in Quebec, Catalonia and Scotland. London: Palgrave Macmillan.

Keating, M. (2001b). Rethinking the Region: Culture, Institutions and Economic Development in Catalonia and Galicia. European Urban and Regional Studies, 8(3), 217-234. DOI: 10.1177/096977640100800304. 
Lepič, M. (2017). Limits to Territorial Nationalization in Election Support for an Independence-Aimed Regional Nationalism in Catalonia. Political Geography, 60, 190-202. DOI: 10.1016/j.polgeo.2017.08.003.

Mercadé, F. (1982). Cataluña: intelectuales políticos y cuestión nacional. Barcelona: Peninsula.

Oskam, J. (2014). A New State in Europe? Scenarios for Catalan Self-Determination. Futures, 64, 51-60. DOI: 10.1016/j.futures.2014.10.008.

Ovejero, F. (2018). El nacionalismo Catalán: De las mentiras de la política a la política de las mentiras. Cuadernos Hispanoamericanos, 816, 67-81.

Payne, J. (1991). Catalonia: Portrait of a Nation. London: Random Century.

Petschen, S. (1992). La Europa de las regiones. Barcelona: Generalitat de Catalunya, Institut d'Estudis Autonòmics.

Prat de la Riba, E. (1987). La nacionalidad catalana. Madrid: Alianza Editorial.

Propuesta de Reforma de Estatuto de Autonomía (2005). Boletín Oficial de las Cortes Generales. B-210-1 de 21 de octubre de 2005. Cortes Generales. Retrieved from: www.congreso.es.

Pujol, J. (1976). Una política per Catalunya. Barcelona: Nova Terra.

Pujol, J. (1980). Construir Catalunya. Barcelona: Pòrtic.

Pujol, J. (1996). Cataluña - España. Madrid: Espasa Calpe.

Resolució 98/II del Parlament de Catalunya, sobre el dret d'autodeterminació de la nació catalana - Buletí Oficial del Parlament de Catalunya, 18 December 1989, No 120.

Resolució 1/XI del Parlament de Catalunya (2015).

Rivero, G. (2015). Heterogeneous Preferences in Multidimensional Spatial Voting Models: Ideology and Nationalism in Spain. Electoral Studies, 40(C), 136-145. DOI: 10.1016/j.electstud.2015.06.002.

Smith, A. (2014). The Origins of Catalan Nationalism, 1770-1898. Basingstoke-London: Palgrave MacMillan.

Tortella, G., García Ruiz, J.L., Núñez, C.E., \& Quiroga, G. (2016). Cataluña en España: historia y mito. Madrid: Gadir y la Fundación Alfonso Martín Escudero.

Tuñon de Lara, M., Valdeón Baruque, J., \& Domínguez Ortiz, A. (2003). Historia de España. Valladolid: Ambito.

Vargas, M. (2018). Constructing Catalan Identity: Memory, Imagination, and the Medieval. Cham: Palgrave MacMillan.

Viu, C. (1998). El nacionalismo catalán como factor de modernización. Barcelona: Quaderns Crema. 